\title{
18. CAPE BOJADOR SLOPE, AN EXAMPLE FOR POTENTIAL PITFALLS IN SEISMIC INTERPRETATION WITHOUT THE INFORMATION OF OUTER MARGIN DRILLING
}

\author{
G. Wissmann, Federal Institute for Geosciences and Natural Resources, BGR, Hannover, West Germany
}

\begin{abstract}
During its evolution, the continental slope is frequently scoured by erosional events which may not always show up as unconformities on the seismic record. Pitfalls await the seismic interpreter, especially in the lower slope region where many of these unconformable reflectors merge and meet with the seemingly simple, conformably bedded horizons of the upper rise. In this setting, the acoustostratigraphy should be checked by drilling and refined by logging. Examples of pre- and post-Site 397 interpretation of profiles across the Cape Bojador continental margin are presented. They prove that slumps not clearly resolved with low-frequency airgun records mimic the continuation of reflectors from the lower slope to the rise and cause erroneous acoustostratigraphic identifications. Information about the undrilled section and the regional setting is discussed together with refraction seismic data. This results in a warning not to stratigraphically correlate layers with the same refraction velocities in the zone of facies change on the continental slope and upper rise.
\end{abstract}

\section{PRESITE REFLECTION SEISMIC INTERPRETATION}

Two distinct unconformities $\left(D_{1}\right.$ and $D_{2}$ of Hinz et al., 1974) divide the sediment section on the continuous seismic records of the northwest African continental margin southeast of the Canary Islands.

Before Site 397 was drilled, reflection seismic profiles gave inconclusive evidence as to whether $D_{1}$ and $D_{2}$ could be traced down to the continental rise over the enigmatic lower slope anticline structure.

On some profiles (Meteor 25-A2 and 39-14, Valdivia 10-6 and 12) in Seibold and Hinz (1976), it seemed possible to correlate $\mathrm{D}_{2}$ with the first strong, although concordant, reflector at $4.8 \mathrm{sec}$ within the uppermost rise sediments (Figure 1).

On other profiles (Meteor 25-1 and 3, Valdivia 10-1, 3, 4, 8, 10 in Seibold and Hinz, 1976; Atlantis II-117 and 118 in Uchupi et al., 1976), this "rise- $\mathrm{D}_{2}$ " and the overlying Neogene reflectors appear to lap onto an escarpment. This scarp was carved into the Lower Cretaceous slope sediments by the erosional events, which are represented by Reflectors $D_{1}$ and $D_{2}$ on the slope. The tracing of the discordancies was severely hampered by the large vertical exaggeration $(>\times 10)$ of the analog profiles.

Because of many diffractions under the slope, the GSI digital profile A1L (see Site Report, this volume) could not solve this controversy. But the profile showed more than $2 \mathrm{~km}$ of nearly horizontal strata under the "slope anticline." This disproved the presence of a deep-seated structure such as a basement high, of which the anticline was supposed to be the surficial expression (Lancelot, Seibold, et al., 1977).
Before drilling Site 397, it still seemed possible to trace the unconformities, at least on reference profile Meteor 25-2 (Figure 1), down the continental slope into the conformable marker reflectors within the upper continental rise sediments. Therefore, the sediments bounded by the reflectors under the uppermost rise were thought to represent the same time-stratigraphic unit as those found under the upper slope and shelf.

The sequence there between $D_{1}$ and $D_{2}$ was interpreted as representing transgressive Upper Cretaceous marine sediments. Hinz et al. (1974, their fig. 2) and later Seibold and Hinz (1974) thought that the post- $D_{1}$ strata were transgressive, because sediments deposited immediately above $\mathrm{D}_{1}$ show a concordant to onlapping relationship to the unconformity. However, the complete sequence between $D_{1}$ and $D_{2}$ under the middle and lower slope would best be described as being constituted of offlapping sediments (Hinz, this volume).

With the use of sonic log information, the underlying unconformity $\mathrm{D}_{1}$ could be extrapolated to conformable Middle Cretaceous strata in onshore oil wells (A.U.X.I.N.I., 1969). After Mitchum and Vail (1978), the ages of unconformities are determined from well control, where the hiatuses are at a minimum (see frontispiece). Thus, $D_{1}$ was assumed to be of Cenomanian age and $D_{2}$ was estimated to be of Oligocene to early Miocene age.

\section{LEG 41 AND 47A DRILLING INFORMATION CORRELATED WITH A NEW PROFILE (Meteor 46-37)}

DSDP/IPOD Sites 369 and 397 translated the geophysical parameters into geological reality. Unfortunately, however, both holes were not logged. Because 


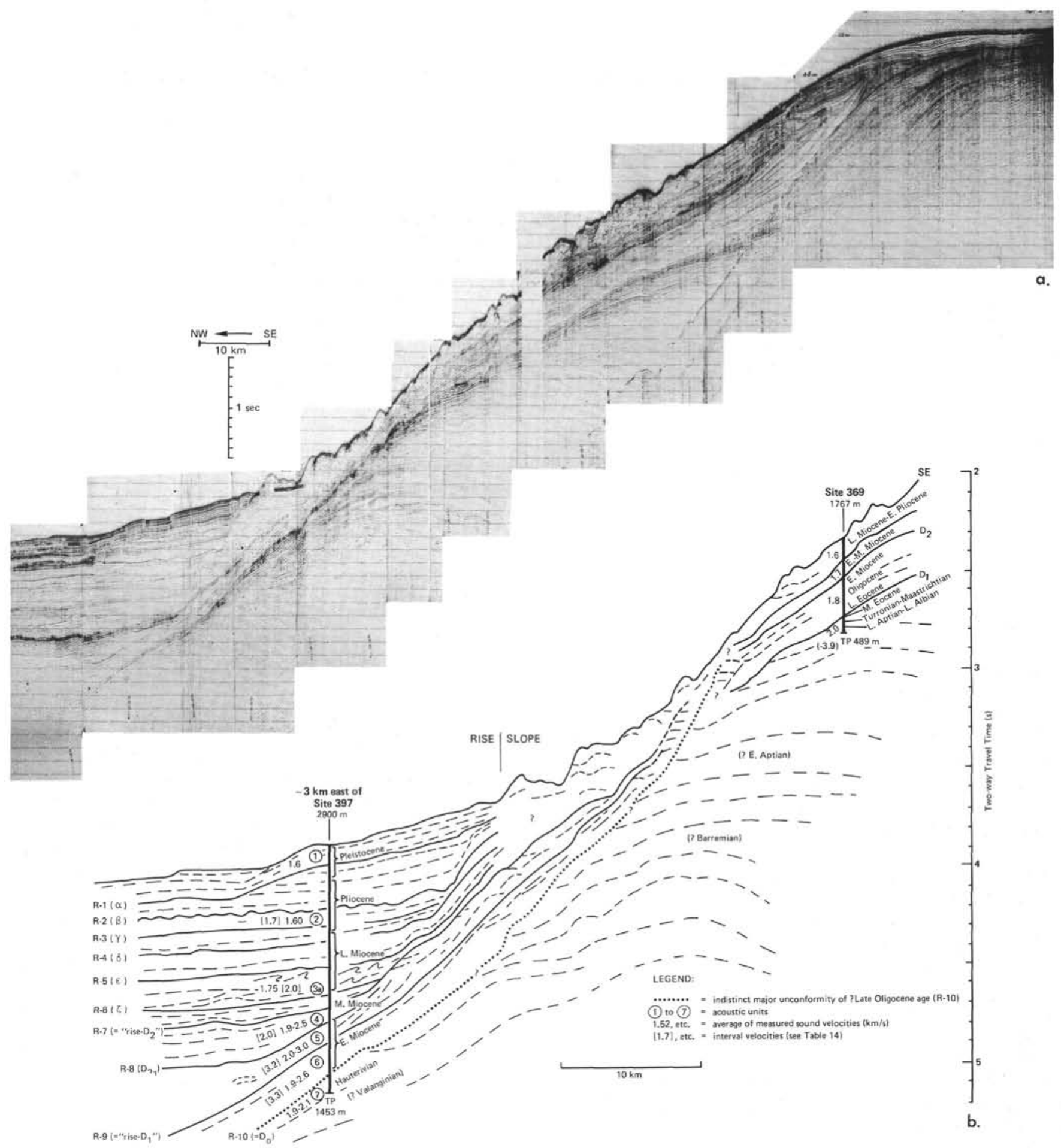

Figure 1. Seismic reflection profile (Meteor 25-A2) across the African continental margin, northwest of Cape Bojador. Line crosses DSDP Site 369 and is within 3 km of Site 397 (see Arthur et al., Leg 47 Synthesis, fig. 1 for location map). (A) Original analog record (horizontal lines spaced at 0.1-sec intervals two-way travel time). (B) Line drawof the same profile showing acoustic reflectors identified in Sites 369 and 397 (see also Sediment Summary Chart 1, in back pocket). 
of a broad scatter in the Hamilton Frame velocities (Mountain, this volume) and differences between coremeasured values and inferred average interval velocities (at Site 369 possibly due to drilling disturbance), the correlation between lithology and seismic reflectors remains somewhat difficult. Future drilling efforts to penetrate the continental slope and uppermost rise should be logged to resolve the many consecutive hiatuses typical for this zone.

In the framework of a Leg 41 and Leg $47 \mathrm{~A}$ postcruise survey by the BGR in November of 1977 , profile Meteor 46-37 was shot to help interpret the reflectors under the Cape Bojador continental slope. Figure 2 shows an interpretation of this profile which connects Sites 369 and 397.

$\mathrm{D}_{1}$ of Site 369 is now interpreted as the angular unconformity which correlates with an abrupt change in lithology where soft Oligocene to upper Eocene marls overlie hard middle Eocene limestones (Lancelot, Seibold, et al., 1977). The late Eocene age for $D_{1}$ correlates well with the Paleogene beginning of continental slope erosion by the incision of submarine canyons (Wissmann in von Rad et al., in press, their fig. 4a).

$\mathrm{D}_{1}$ erosionally truncates Paleogene and Cretaceous sediments which increase landward in thickness. Under the present shelf, Upper Cretaceous sediments reach a thickness of 900 meters (Spansah 51 A-1, see Arthur et al., Leg 47A Synthesis; see also Querol, 1966, p. 32), whereas at Site 369 they are only 60 meters thick. Thus, the seismic profiles show a hiatus which changes in duration and which spans $7 \mathrm{~m}$.y. between middle Eocene (P.12) and upper Eocene (P.17) at Site 369.

$\mathrm{D}_{2}$ at Site 369 corresponds to a lithologic change from nannofossil marls to underlying siliceous nannofossil marls within the early Miocene. However, $\mathrm{D}_{2}$ should also represent a hiatus, which has not been detected biostratigraphically in the sediment samples (perhaps 1 m.y., NN 6).

Higher up the slope, the reflector neatly exhibits its origin through erosional truncation, e.g., Meteor 25-A2 (Figures 1 and 3).

Unconformities $D_{1}$ and $D_{2}$ merge at the slope/rise boundary, where they are covered by a thin veneer of early Miocene (and younger) hemipelagic sediments.

Detailed study of single and multichannel seismic profiles from the Cape Bojador continental margin has clarified the acoustic character and lateral extent of major reflectors. However, to date the continental rise reflectors, it is still necessary to connect the many profiles crossing the continental margin by a profile over the uppermost rise parallel to the foot of the slope. This is required because several consecutive erosional events in the Cretaceous (Albian), Paleogene (?Paleocene and Eocene), and Neogene (early Miocene, late Miocene, Pliocene) have eliminated the local record of previous erosional phases.

With reduced ship speed to better delineate the location of the reflectors, the new profile (Meteor 46-37) clearly demonstrates that the slope reflectors must not be continued onto the rise (Figure 2).
Looking at the upper rise we see that Reflectors $D_{1}$ and $\mathrm{D}_{2}$ of Hinz et al. (1974) lap onto a steep erosional escarpment which is present under the lower slope (Figure 2). Therefore, these reflectors must be younger than the two unconformities under the part of the slope that forms the escarpment (maximum dip $15^{\circ}$ ).

The former "rise- $\mathrm{D}_{2}$ " reflector is now interpreted as being middle Miocene volcaniclastic debris flow "V-1" (Schmincke and von Rad, this volume), and the underlying "rise- $\mathrm{D}_{1}$ " reflector is the 20 to 30 meters thick, mixed, volcanogenic-sedimentary debris flow "V-4", (see Arthur and von Rad, this volume) within pebbly mudstones of early Miocene age. The stratigraphic record of Site 397 and the structure of configuration as seen on the seismic profile (Figure 2) prove that reflectors from Hauterivian to Paleogene age cannot be continued from the rise to the slope.

\section{REVISION OF REFLECTOR NOMENCLATURE}

Uchupi et al. (1976) have presented profiles (their fig. 26) where they correlate the " $D_{1}$ " reflector from the rise to the shelf with Horizon A (thought to be of early to middle Eocene age). According to post-Leg 47 information, this cannot be correct. At least in their Profile 117 off Cape Bojador, an early Miocene age is certain for their "Horizon A" under the rise province.

A new nomenclature for seismic stratigraphy of the Cape Bojador margin is needed, which should be differentiated geographically as follows: (1) Under the shelf and slope we continue to identify the two major reflectors which mark the unconformities (of revised age) as $D_{1}$ and $D_{2}$. (2) Under the rise in the vicinity of Site 397, we use the reflector designations in the Site Report (this volume).

\section{ARGUMENTS ABOUT THE ERODED SLOPE ESCARPMENT}

The processes which caused the formation of the slope anticline, the erosional truncation of the slope, and the time during which 1 to $3 \mathrm{~km}$ of slope sediments were removed are not yet understood (Arthur et al., this volume). A clue to these problems may be found in the configuration of the buried erosional surface.

Like the underlying "slope anticline" (see fig. 1 in Arthur et al., Leg 47A Synthesis, this volume), the strike of the erosional escarpment on Meteor 46-37 curves into an east-west direction perpendicular to the coast near $27^{\circ} \mathrm{N}$. As identified below, three factors could have influenced this change of direction.

1) The emerging shield-building volcanoes of Lanzarote and Fuerteventura deflected southward flowing oceanic currents against a slope under which the "slope anticline" had already formed. In the area of Meteor 39-14 (Seibold and Hinz, 1976, fig. 3) these hypothetical erosive currents should have been active in water depths between 500 to 2200 meters. This explanation is not too satisfactory, as the east-west segment of the erosional truncation surface should then have become a natural levee. The seismic records, however, show the northeast- 


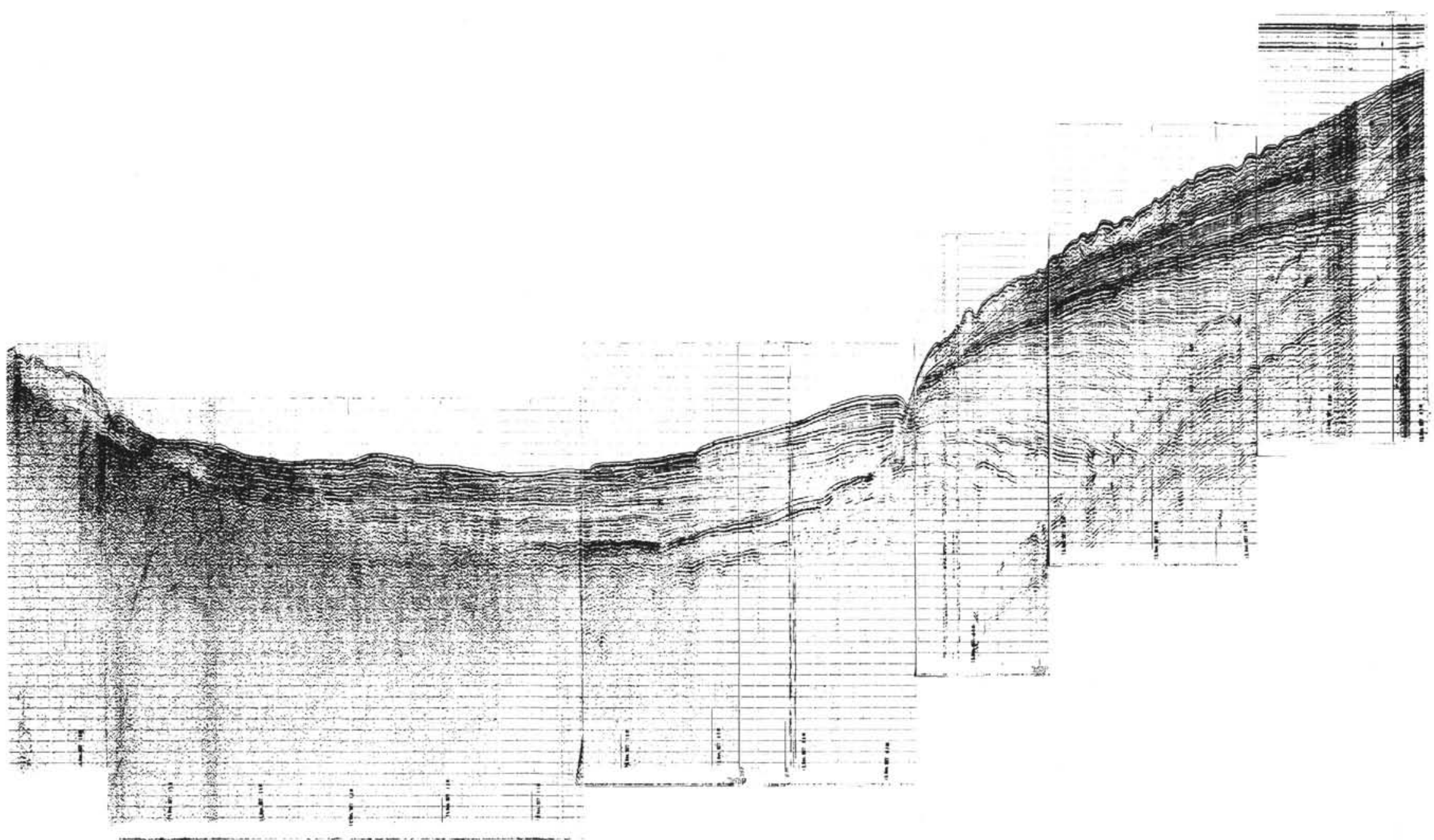

Figure 2a. Seismic reflection profile (Meteor 46-37) across the outer Cape Bojador continental margin connecting DSDP Sites 369 and 397 (see fig. 1 of Arthur et al., Synthesis, this volume). Original analog record (horizontal lines spaced at 0.1-sec intervals two-way travel time). For digital display of this single-channel profile, see Site 397 Report, fig. 24. 


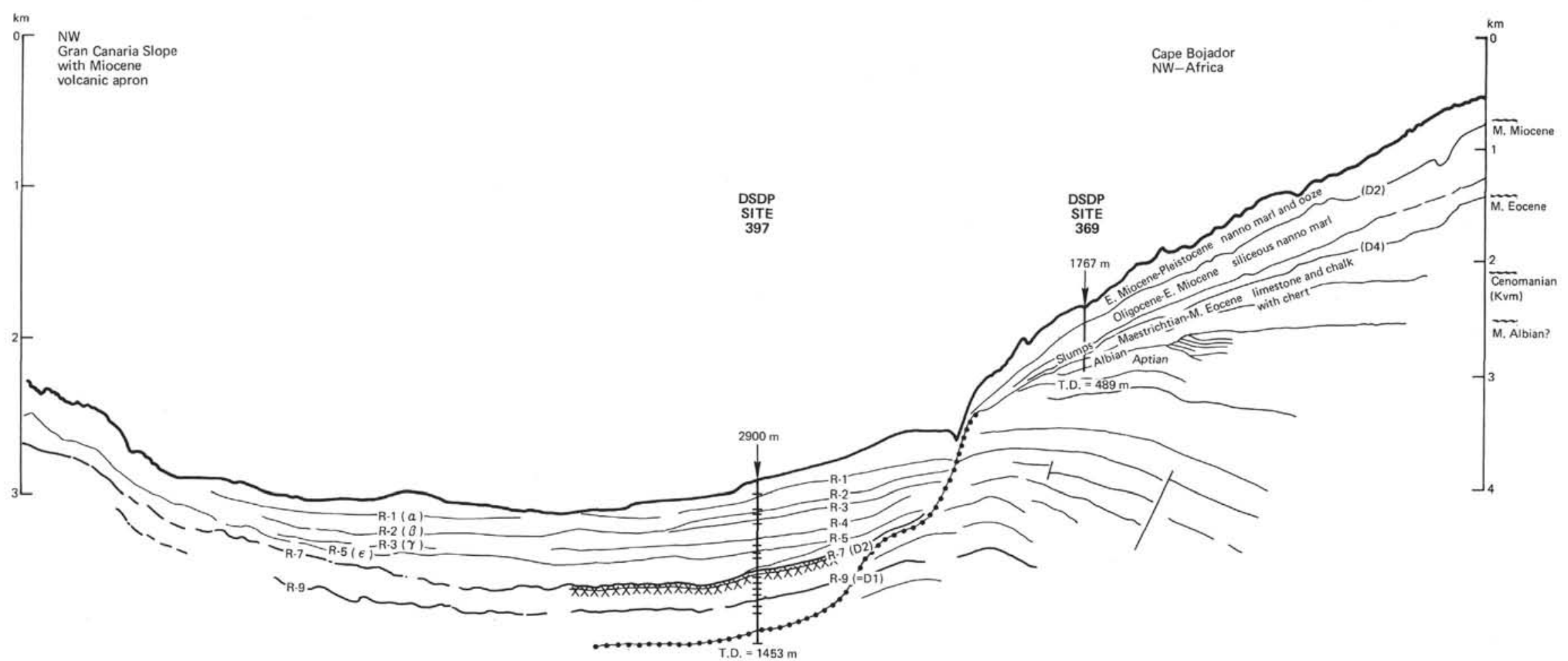

V.E, $\sim 15 x$

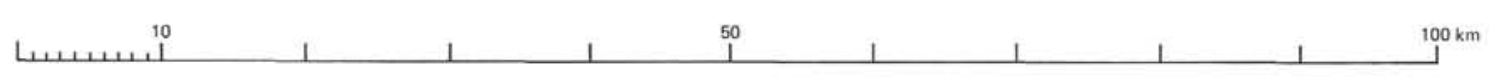

$\mathrm{X} X \mathrm{X}$ extent of volcaniclastic debris flow from Fuerteventura (Schmincke and von Rad, this volume) ...... major mer Early Neogene/Early Cretaceous unconformity

Figure 2b. Seismic reflection profile (Meteor 46-37) across the outer Cape Bojador continental margin connecting DSDP Sites 369 and 397 (see fig. 1 of Arthur et al., Synthesis, this volume). Line drawing of the same profile showing acoustic reflectors identified in Sites 369 and 397 (see also Sediment Summary Chart 1, in back pocket). 
Late Miocene

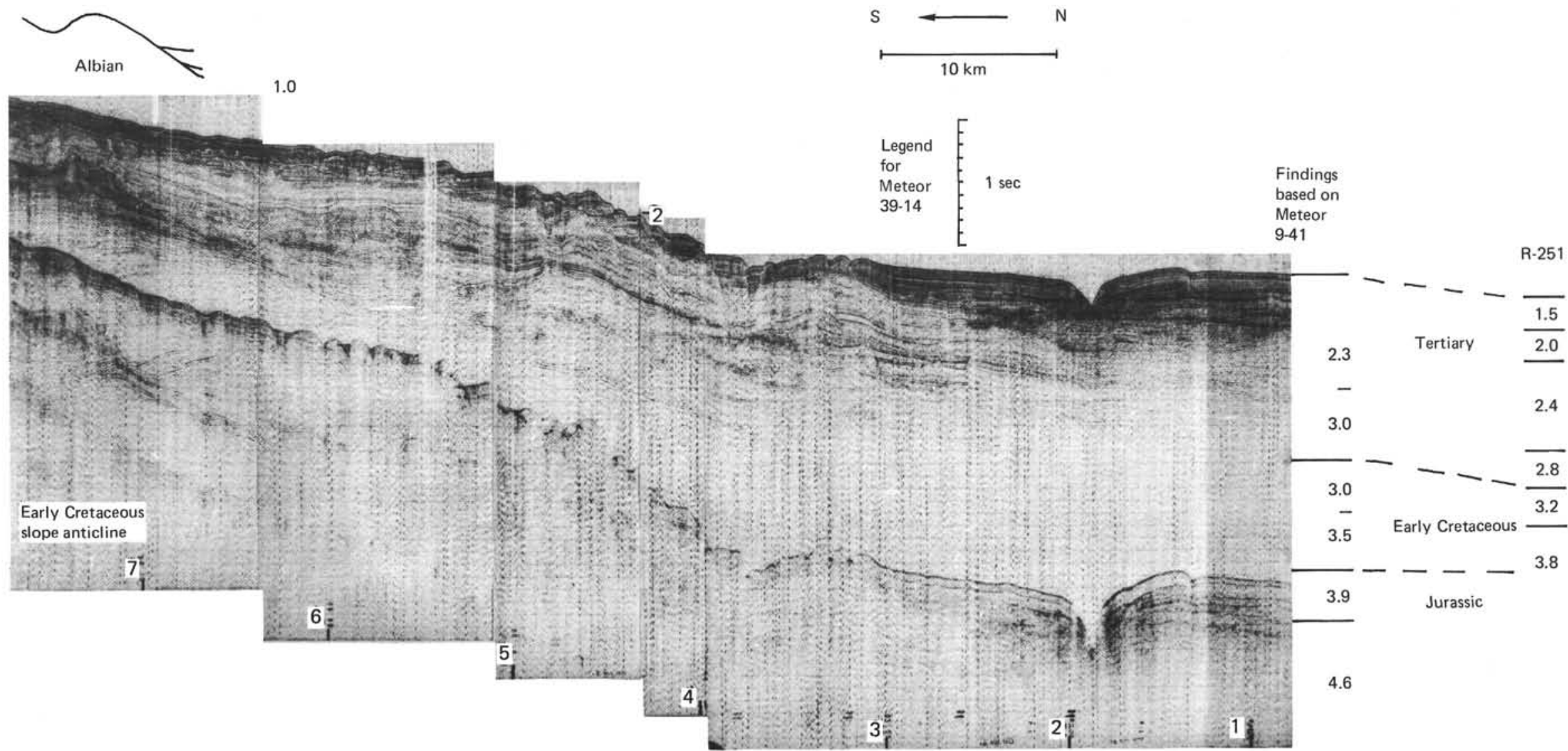

Figure 3. Profile Meteor 39-14 showing "slope anticline." The extension of the "slope anticline" to the north of Cape Bojador was missed on many profiles running obliquely or parallel to its strike direction. Profile Meteor 39-14 proved that the axis of this high in the Cretaceous section changes direction and runs nearly perpendicular to the coast. Taking refraction velocities as interval velocities, the results of two refraction stations along the profile have been stratigraphically interpreted (for locational map, see fig. 1 of Arthur et al., Synthesis, this volume). 
southwest escarpment to be steeper; thus, the eroding currents may have come from another direction. Today, a quasipermanent northward-flowing undercurrent occurs below 400 meters off Cape Bajador. It is $30 \mathrm{~km}$ wide and moves with a mean speed of $10 \mathrm{~cm} / \mathrm{sec}$; the Coriolis deflection allows it to impinge upon the slope (Mittelstaedt et al., 1975).

2) A right-lateral fracture zone may have offset the continental margin during the Miocene. There are no traces of such an event in the reflection profiles, except the curious southern termination of possible Jurassic salt diapirs (Lehner and de Ruiter, 1977) and an eastern spur of the volcanic socle of Fuerteventura (fig. 4 in Roeser et al., 1971).

3) Another factor to be considered is the possible existence of a Miocene delta offshore from the present Sequia el Hamra dry river, which may have been erosionally active. Oil well Daora 1-1 drilled through 1100 meters of Miocene sediments on Lower Cretaceous strata (A.U.X.I.N.I., 1969) provides support for this interpretation, but the mechanism of erosion remains unknown.

The gradients of the erosional escarpment decreases gradually from the lower slope to the uppermost rise. The erosional surface there represents an approximately 100-m.y. hiatus (R-10, see Site 397 Report) between mudstones of early Miocene and Hauterivian age. There is not enough impedance contrast across this unconformity to produce a significant reflector, which could be mapped areally. The only indirect clue for a hiatus in the seismic record is the well-stratified section of Neogene reflectors which gives way to a diffuse set of incoherent reflection segments underneath (Figure 4). Insufficient power of the seismic source does not seem to be the cause for the lack of resolution as three 5-liter airguns fired at 140 bars used on Meteor Cruise 46 gave no improvement over one 5-liter airgun fired at 120 bar on Meteor Cruise 25.

The northwest-trending Meteor 46-37 profile (Figure 2) extends to the middle Miocene volcanic apron of Gran Canaria Island, under which reflections of older sediments can no longer be distinguished on singlechannel reflection profiles. Analysis of a 1967 refraction station at this point provided some information about the deeper section.

\section{DISCUSSION OF UNDRILLED REFRACTION LAYERS}

The unreversed eastern half of the split-profile twoship refraction station Meteor $9-42\left(27^{\circ} 44.5^{\prime} \mathrm{N}\right.$, $14^{\circ} 47.0^{\prime} \mathrm{W}$ ) indicates the presence of about $3 \mathrm{~km}$ of unconsolidated sediments with a velocity of $2.4 \mathrm{~km} / \mathrm{sec}$ under the volcanic apron (Figure 5). These sediments overlie rocks having an updip apparent velocity between 5 and $6 \mathrm{~km} / \mathrm{sec}$. They could constitute the volcanic pedestal of the ridge between Gran Canaria and Fuer- teventura because the velocity of oceanic basement in this area is quoted as $6 \mathrm{~km} / \mathrm{sec}$ from multichannel profiles (Grunau et al., 1975).

Based upon their stratigraphic position in reflection profiles, it is possible that the unconsolidated sediments are marine equivalents of the clastics of the Wealden-type Tan-Tan delta (Choubert et al., 1966) or the Jreibichat formation. They would then be coeval with the Cretaceous Africa-derived deep-sea quartz sandstones uplifted on the west coast of Fuerteventura (Schmincke, 1976).

But, as with the tracing of seismic reflectors, caution should also be exercised when correlating strata with the same refraction velocities. As shown in the Meteor 39-14 profile (Figure 3), the same velocity of $2.4 \mathrm{~km} / \mathrm{sec}$ (refraction stations Meteor 9-41, Roeser et al., 1971; R 251, Hoskins et al., 1975) near the African margin does not represent Lower Cretaceous strata; instead it represents upper Miocene sediments. These Neogene to Recent sediments and volcaniclastics can reach thicknesses of more than $1 \mathrm{~km}$ east of Fuerteventura (Figure 4).

Further analysis and compilation of reflection seismic data are needed to show where Upper Cretaceous and Paleogene sediments reappear under the intermediate continental rise off Cape Bojador seaward of the major foot-of-slope unconformity.

\section{ACKNOWLEDGMENTS}

The Valdivia and Meteor profiles analyzed were financed by the Federal Ministry of Research and Technology (BMFT) and the German Research Foundation (DFG). Thanks to Dr. Emery for providing apico copies of his Profiles 117 and 118 off Cape Bojador, and to the British Petroleum Company for insight into GSI multichannel profiles off northwestern Africa. The paper was critically reviewed by Dr. von Rad, whose comments along with those of Dr. Hinz were gratefully accepted.

\section{REFERENCES}

A.U.X.I.N.I., 1969. Correlación estratigráfica de los sondeos perforados en el Sahara español, Spain, Inst. Geol. Minero, Bol. Geol. Minero, v. 80, p. 235-251.

Choubert, G., Faure-Muret, A., and Hottinger, L., 1966. Apercu géologique du bassin cotier de Tarfaya, Notes et Mém. Serv. Géol. Maroc, no. 175, p. 9-97.

Grunau, H.R., Lehner, P., Cleintuar, M.R., Allenbach, P., and Bakker, G., 1975. New radiometric ages and seismic data from Fuerteventura (Canary Islands), Maio (Cape Verde Islands), Progress in geodynamics, Amsterdam.

Hinz, K., Seibold, E., and Wissmann, G., 1974. Continental slope anticline and unconformities off West Africa, "Meteor'-Forschungsergeb., ser. C, p. 67-73.

Hoskins, H., Rogers, C.U., and Woo, E.O., 1974. Data report of oblique reflection-refraction radio sonobuoy profiles on the African Atlantic continental margin ( $R / V$ Atlantis II Cruises 67 and 75), Technical Report WHOI, ref. no. 7434.

Lancelot, Y., Seibold, E., et al., 1977. Site 369. In Lancelot, Y., Seibold, E., et al., Initial Reports of the Deep Sea Drill- 


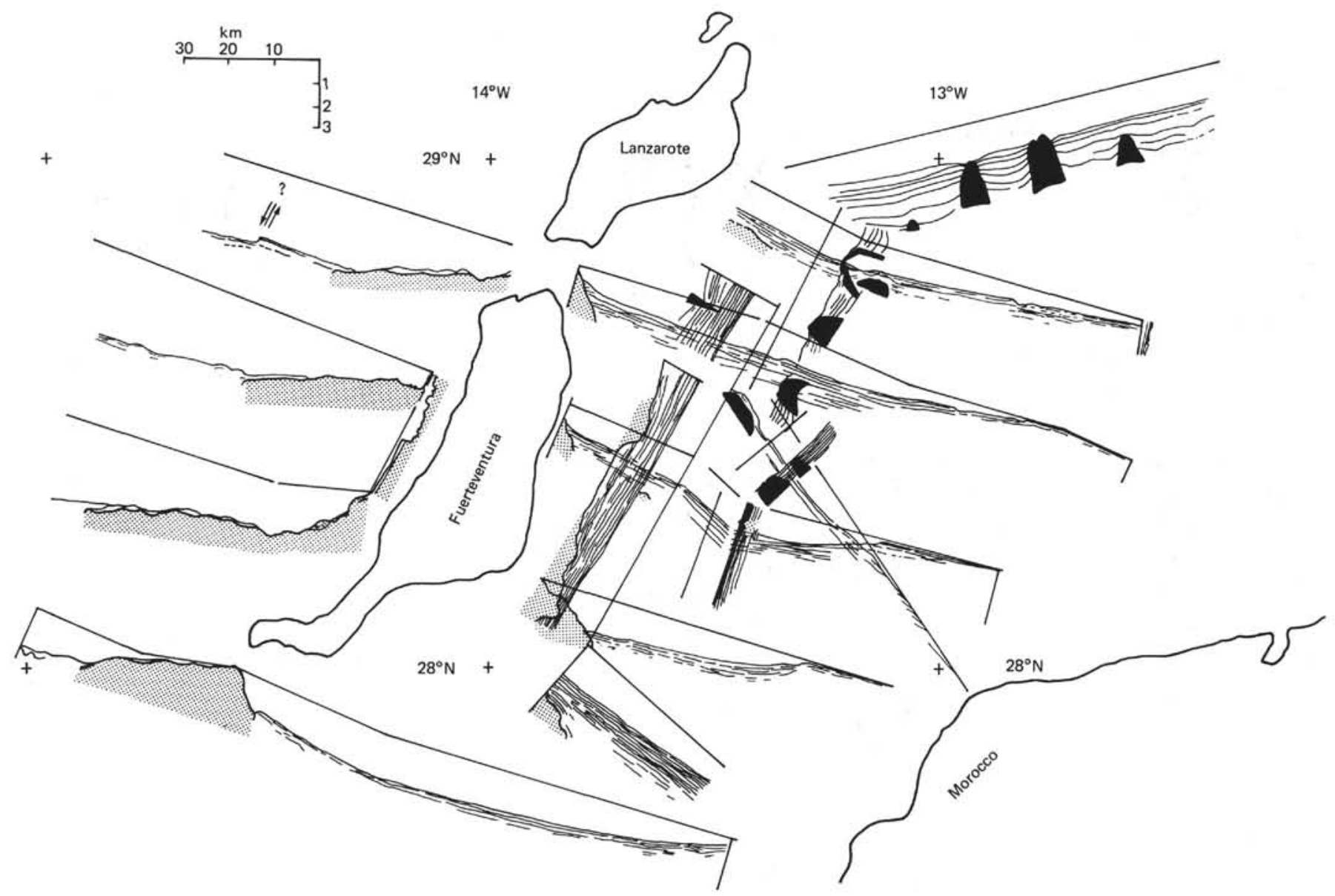

Figure 4. Sections of depth converted reflection profiles. The zero depth line is represented by the top of the cruise track. Most sediments shown on the northwest-southeast trending profiles are of Neogene to Recent age. The other profiles may represent some Lower Cretaceous sediments in the deeper parts, which is here characterized as a transparent reflection-free zone (see Figure 3). The interpreted volcanic pedestal of the East Canary Ridge is stippled; diapiric structures of possible Jurassic salt are filled in black. Mesozoic sediments may have been uplifted by the recently mobilized diapirs and the Miocene emergence of Fuerteventura.

ing Project, v. 41: Washington (U.S. Government Printing Office).

Lehner, P. and De Ruiter, P.A.D., 1977. Structural history of Atlantic margin of Africa, Am. Assoc. Petrol. Geol. Bull., v. 61, p. $961-981$.

Mitchum, R. M., Jr. and Vail, P. R., 1978. Seismic stratigraphic interpretation procedure. In Vail, P.R., et al., Seismic stratigraphy and global changes of sea-level, $\mathrm{Am}$. Assoc. Petrol. Geol. Mem. p. 26.

Mittelstaedt, E., Pillsbury, D., and Smith, R.L. 1975. Flow patterns in the Northwest African upwelling area, Deutsche Hydrograph Zeitschrift, v. 28, p. 145-167.

Querol, R., 1966. Regional geology of the Spanish Sahara. In Reyre. d. (Ed.), Sedimentary basins of the African coasts, pt. 1, Atlantic coast, Paris, Assoc. African. Geol. Survey, p. 27-39.

Roeser, H. A., Hinz, K., and Plaumann, S., 1971. Continental margin structure in the Canaries, Report 70/16, Inst. Geol. Sciences, London, p. 27-36.
Schmincke, H.U., 1976. The geology of the Canary Islands. In G. Kunkel (Ed.), Biogeography and ecology in the Canary Islands: The Hague (Dr. W. Junk).

Seibold, E. and Hinz, K., 1974. Continental slope construction and destruction, West Africa. In Burk, C.A. and Drake C.L. (Eds.), The geology of continental margins: New York (Springer-Verlag), p. 179-196.

, 1976. German cruises to the continental margin of North West Africa in 1975: General reports and preliminary results from Valdivia-10 and Meteor-39, MeteorForsch.-Ergebnisse, Reihe C, v. 25. p. 47-80.

Uchupi, E., Emery, K.O., Bowin, C.O., and Phillips, J.D., 1976. Continental margin off Western Africa: Senegal to Portugal, Am. Assoc. Petrol. Geol. Bull,, v. 60, p. 809-878.

von Rad, U., Čepek, P., von Stackelberg, U., Wissmann, G., and Zobel, B., in press. Cretaceous and Tertiary sediments from the Northwest African slope (dredges and cores supplementing DSDP results), Marine Geol. 